\title{
A framework for use in modelling the modal choice decision making process in North West England's Atlantic Gateway.
}

\author{
Alan BURY, Dimitrios PARASKEVADAKIS, J un REN, Fa rhan SAEED. \\ Liverpool Logistics Offshore and Marine Institute, Liverpool J ohn Moores University, \\ Liverpool, United Kingdom.
}

\begin{abstract}
The task of producing a generic model of the modal choice decision making process is a challenging one. Modal choice is strongly influenced by the infrastructure limitations and geographical constraints of the area in which the decision is being made. With this in mind, addressing modal choice on an individual basis for each region may be the optimal solution. This is the approach adopted in this paper. The creation of a modal choice model is a multistage process of which this paper addresses the first stage, the production a framework of the decision making process. Firstly, a number of criteria that are commonly used in modal choice models are identified. Then a number of gaps in the criteria utilized in previous papers are established. Subsequently, the method used to produce a framework of the decision making process within North West England's Atlantic Gateway is outlined. Through consultation with transport industry experts in North West England, an initial list of sixty eight papers was reduced to thirty six that were considered to be of specific relevance to modem day freight transportation within their region. The criteria used in each of these papers were then, along with furtherindustry input, used to create the foundation on which a modal choice framework specific to the Attantic Gateway could be built A greater understanding of what influences modal choice within this region will allow informed decisions to be made by policy makers on how to more efficiently utilize the available modes of freight transport Having established this, future work can then go on to build upon these findings. This paper recommends that future work is performed to establish the weights of each criteria and sub-criteria within the framework. This should then be followed by establishing industry's perceptions of the best and worst altematives for moving freight within the Atlantic Gateway.
\end{abstract}

Key words - Freight transport, Modal choice, Northem Powerhouse, Atlantic Gateway, North West England.

\section{INTRODUCTION}

Overuse of the road network has led to greater levels of congestion, elevated levels of road surface wear and tear and an increase in transport related air pollution. When taken in combination with the failure of attempts to balance modal split the road network's continuing slide towards breaking point seems to be beyond question. However, circumstances have conspired to present one partic ular region of England with a tabula rasa for the development of new policies to influence the modal split of freight transportation.

England's economy is currently based around a London-centric model. The recent move towards developing what has become known as a Northem Powerhouse is aimed at rebalancing the economy of the nation for the betterment of all of its citizens. The Atlantic Gateway is an integral part of these efforts. At the same time, the devolution of powers and responsibilities from national govemment to regional authorities may provide an opportunity for positive change the likes of which has not be seen in the North of England since the beginning of the industrial revolution.

Different regions are influenced by their own geographical and infrastructure constraints. Devolution ensures that decisions are made locally and are therefore more able to meet local needs. A greater understanding of what influences modal choice within the Atlantic Gateway will allow local policy makers to make better informed decisions on how to accommodate the inc rea sing levels of freight transportation on the existing local tra nsport infra struc ture. 


\section{BACKG ROUND}

The Atlantic Gateway refers to the area of North West England that forms the corridor between Merseyside and Greater Manchester. With Manchester and Liverpool combined having a population of over four million people this represents the largest area of urban population in the United Kingdom outside of London (The Peel Group, 2012). The Atlantic Gateway has been targeted for fifty billion pounds of investment over the next fifty years. This investment is aimed at driving development and growth in urban areas by creating housing, jobs, improving connectivity and upgrading transport and logistics infrastructure. It also provides an approach for informing policy development and establishing national priorities to rebalance the economy (Cheshire and Wa ming ton Local Enterprise Partnership, 2014)

At present the United Kingdom relies predominantly on the transportation of freight by road. Some of this enters the country in ports on the south coast and is then transported the full length of the country to its destination in Scotland. As a result, England has some of the most congested roads in Europe. Using the Port of Liverpool and the Manchester Ship Canal to move goods into the heart of Northem England would go some way to alleviating this problem in the North West of England. The Manchester Ship Canal represents a viable altemative to road. It runs alongside Europe's largest industrial estate (Trafford Park) and currently uses less than ten percent of its freight capacity. The problem lies in convincing freight businesses to utilize altemative transport modes to road. The purpose of this paper is to present a framework that is the first phase in the development of a tool that could ultimately be used by policy makers to influence the modal choice decision making process and produce a shift of freight camiage to more susta inable transport modes.

\section{LTERATURE REVIEW}

Since the publication of its 2001 transport white paper (European Commission, 2001) the European Union has been attempting to rebalance the modal split in Europe to 1998 levels. To this end the EU devised the Marco Polo (European Commission, 2003) and the Motorways of the Seas (European Commission, 2006) programmes as key elements of its policy to achieve the shift of cargo from road to sea. With the current failure of these programmes to deliver their goal the road network's continuing slide towards breaking point seems to be beyond question.

Work in the field of modal choice and the related fields of route choice and camier selection is already extensive with a wide range of approaches having been utilized in the past. Potentially the most popular approaches have been: case studies (Torbianelli, 2000), cost benefit a nalysis (Paixao and Marlow, 2001), SWOTH analysis (De Oses and Castells, 2008) and logit based models (Rich et al., 2009).

Studies tend to either be aimed at the development of a generic equation or ca mied out within a specific geographical region, such as occurred in: France (Gouvemal, Slack and Franc, 2010), Spain (Feo-Valero et al., 2011) and Canada (Brooks and Trifts, 2008). However, national boundaries often conta in within them a variety of different regions, each of which may have their own transport related constraints. As a result, adopting a national approach to modal choice may be considered less effective than adopting a more specific, regional approach.

\section{A. Popular criteria in previous modal choice studies}

Previous work on the subject of modal choice has identified an extensive list of potential factors that may influence the decision making process. These criteria have been utilized in many different studies.

Cost The criterion that cuts straight to the heart of the modal choice issue is cost. From as early as the 1970's many pieces of research have included this factor in their models of the decision making process. Having previously been defined as the "total user cost" (Dial, 1979), the cost criterion can be taken to mean the total a mount of money expended to take the cargo from door to door. This includes tra nsport, hand ling, storage, and a ny other financial outgoings resulting from the movement of the freight. 
Distance The distance that a given route covers is a nother signific ant factor that often occurs in modal choice literature (Cullinane and Toy, 2000; Feo et al., 2011). It has been argued (Paixao and Marlow, 2002) that modal choice is a direct function of distance. In Hjelle (2010) distance was used to argue that the most energy efficient freight routes are those which are based upon cargo movements by road. This conclusion resulted from the low load factor of seabome transport compared with that of road.

Transit Time Transit time, defined as the "door-to-door transport time, including loading and unloading", has been established in numerous previous studies as a signific ant indic ator for freight shippers (Bardi et al., 1989). Although referred to under a vanety of titles; such as: timescale, shipping speed, and wait time; each of these reflects the same issue, the length of time that the rec eiver has to wait to take rec eipt of the cargo after the time of ordering.

Delays Directly connected to transit time is transit time reliability, more commonly referred to as delays or punctuality. This is a nother factor that is commonly included in modal choice models and is therefore believed to heavily influence modal choice decision making (Danielis et al., 2005; Grosso, 2011). It refers to the degree of certainty and predictability in the travel time of a given transp ortation system. The modes of transport with a more reliable transit time provide the shipper with a greater level of assurance that their shipment will amive at its destination within an acceptable range of its scheduled time. It represents the level of confidence that can be placed on the camiers anticipated transit time from door-to-door.

Senice Frequency Service frequency has been identified on numerous occasions as an important indic ator for freight shippers (Grosso, 2011). Beuthe and Bouffioux (2008) define service frequency as the "service per week actually supplied by the camier or the forwarder". Service frequency is also among the criteria used to characterise the future European Motorways of the Sea (European Commission, 2012).

Controllability and Traceability In Cullinane and Toy (2000) the number of article appearances of specified modal choice criteria were assessed and it was found that Controllability/Traceability was amongst the top fifteen criteria used in modal choice studies. The high number of mentions that this criteria receives in modal choice studies appears to make it an essential element of any modal choice decision making framework. However, Controllability (the ability to influence a shipment) and Traceability (the ability to see where a shipment is) are clearly two separate factors.

Market Factors In the past, there have been a number of factors that have been considered in modal choice studies that could be grouped under the heading of market factors. These are those that influence people within an organisation from outside without them nec essa rily knowing. Those that have been studied, include: fina nc ial sta bility (Menon et al., 1998), global c onta iner rates (Bird, 1988), market attributes (Gray, 1982), market considerations (Mangan et al., 2001) and lack of investment (Department for Transport, 2007).

Summary of selected popular criteria from previous modal choice studies The broad employment of this limited collection of criteria may demonstrate that they are indeed those that are most influential on the modal choice decision making process. Altematively, it could be that researchers are creating an echo chamber effect within which a limited number of criteria are included in an increasingly large number of models. This may be due to a lack of imagination amongst researchers, a lack of engagement with industry, or a belief that highly educated, likeminded researchers are infa llible.

\section{B. Under represented criteria in previous modal choice studies}

Some criteria, although they are stated as being of relevance when discussing modal choice with industry representatives, are not signific antly covered in the existing models. The most signific ant criteria of this sort that were identified through this work are:

Pollution Whilst energy efficiency is of importance when considering the distance that a given route covers it is also of importance with regard to the extemal impacts (pollution) resulting from freight transportation. The more energy required to move a cargo from its origin to its destination the more pollution that will be produced (Hjelle, 2010). In the past, work has been done to identify the gaps in modal choice and camier selection research (Meixell and Norbis, 2008). Environmental 
concems were found to be a theme that was entirely missing in their body of research. None of the forty eight artic les reviewed by Meixell and Norbis had any mention of these issues in them.

Security A definition of security in a conta inerised supply chain is "the physical and procedural security standards of the various commercial perimeters e.g. warehouse, conta iner consolidation facilities" (Riahi, 2010). In a similar way to how pollution has been overlooked in previous studies of the modal choice decision making process, security is also under represented. Only one paper from all of those selected by Meixell and Norbis considered security. In that paper (Voss et al., 2006) sec unity was identified a s a potential new criterion for inclusion in future modal choice studies.

Claims Processing The idea of claims processing as a criterion influencing modal choice is suggested in Wong et al. (2008). This paper is aimed at modal choice in China where the legal structure surrounding claims awards compensation to both the plaintiff and the defence in a case. Under these circumstances the efficiency with which claims can be processed is of concem to everyone involved. The legal system in the United Kingdom is different but with cla ims processing being omitted from many of the existing modal choice studies this represents an oversight in many models.

Safety Record The model produced by Gursoy (2010) includes "shipping safety" as a criterion that is "assumed to be effective in the shipping mode choic es of shippers". However this criterion is not commonly found amongst the multitudes of other papers covering modal choice. This lack of mention of a mode or company's safety record in many models represents a gap in the study of modal choice.

Image of Mode Having had discussions, off the record, with a number of operators in the freight industry it was found that shippers have a biased image in their mind of what a given transport mode has to offer. It was hoped that this would be addressed by the work done by the University of Westminster to analyse the strengths and weaknesses of the road, rail and water modes of transportation (Department for Transport, 2007). However, the freight operators that were spoken to for this paper, have identified what they refer to as the 'image of a mode' as being highly relevant to the decision making process that they go through when selecting a transport mode. This may be the case but modal image is not a criteria that has been captured in previous models.

Finances The finances of a company can be a diffic ult criterion to collect data for. It is for this reason that many studies of the modal choice decision making process choose not to include it. However, The United Kingdom's Department for Transport identified financial conditions as playing a role in modal choice (Department for Transport, 2007).

Summary of the selected under represented criteria from previous modal choice studies The absence of this collection of criteria from the majonity of previous modal choice models may have been an oversight or it may have resulted from them being perceived as not having an impact upon modal choice. However, regardless of which may be the case, their omission from previous studies represents a series of gaps in the understanding of the decision making process.

\section{METHODOLOGY}

To develop the framework that is presented in this paper, the following procedure was followed:

A. Identific ation of the criteria that influence the modal choice decision making process (Step One)

To understand the processinvolved in making a modal choice the first major step is to determine the factors that influence the decision making process (D'Este and Meyrick, 1992). The qualitative and quantitative criteria that influence freight transportation modal choice decision making have been widely examined in the past. A review of the literature that covers the field of modal choice was performed and identified sixty eight signific ant joumal pa pers from the last thirty five years.

A list of the criteria identified in these papers was passed to management staff within North West England's freight transport industry. Those consulted evaluated the relevance of the various criteria to today's transport industry in North West England. Their work allowed the initial list of papers to subsequently be reduced from sixty eight to thirty six that were considered to have the most relevance to modem day freight transportation in North West England. These papers are listed, in 


\section{chronological order, in Table 1.}

Table 1: A chronological list of the thirty six papers utilized in the development of the framework.

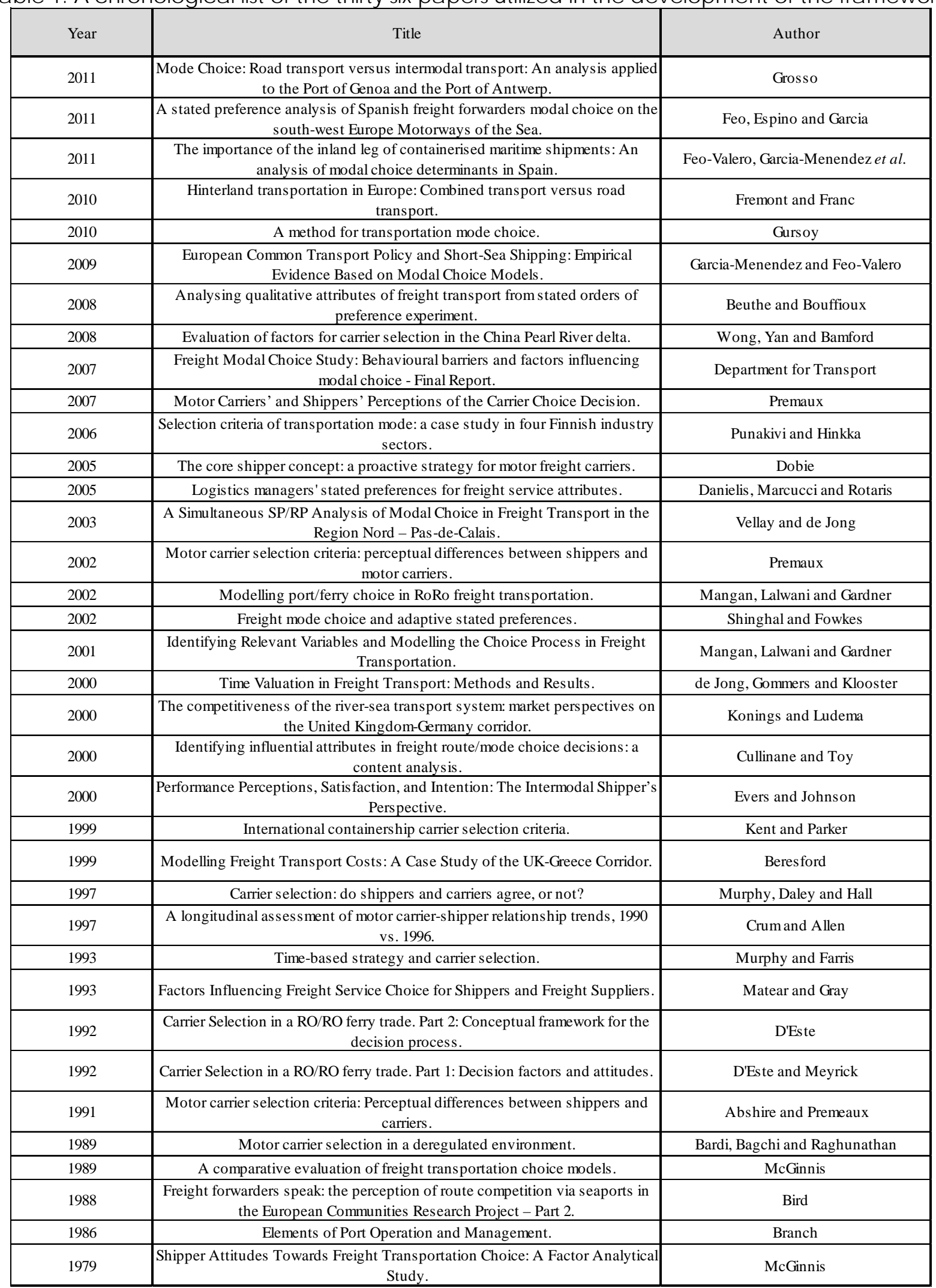

Source: Own. 
From these papers an extensive list of potential criteria were identified. All of the terms found in these papers, along with contributions made by representatives of industry, were compiled in to a list.

\section{B. Group similar criteria together under individual hea dings (Step Two)}

In step one of this process, consultation with industry, in conjunction with a review of thirty six selected papers, was used to construct a list of terms typic ally identified as influencing the modal choice decision making process. A wide variety of terms to identify individual criterion have been used in previous modal choice decision making studies. The tems used in this work are a combination of those which are most commonly encountered in the research literature and those which a re currently in use in the freight industry.

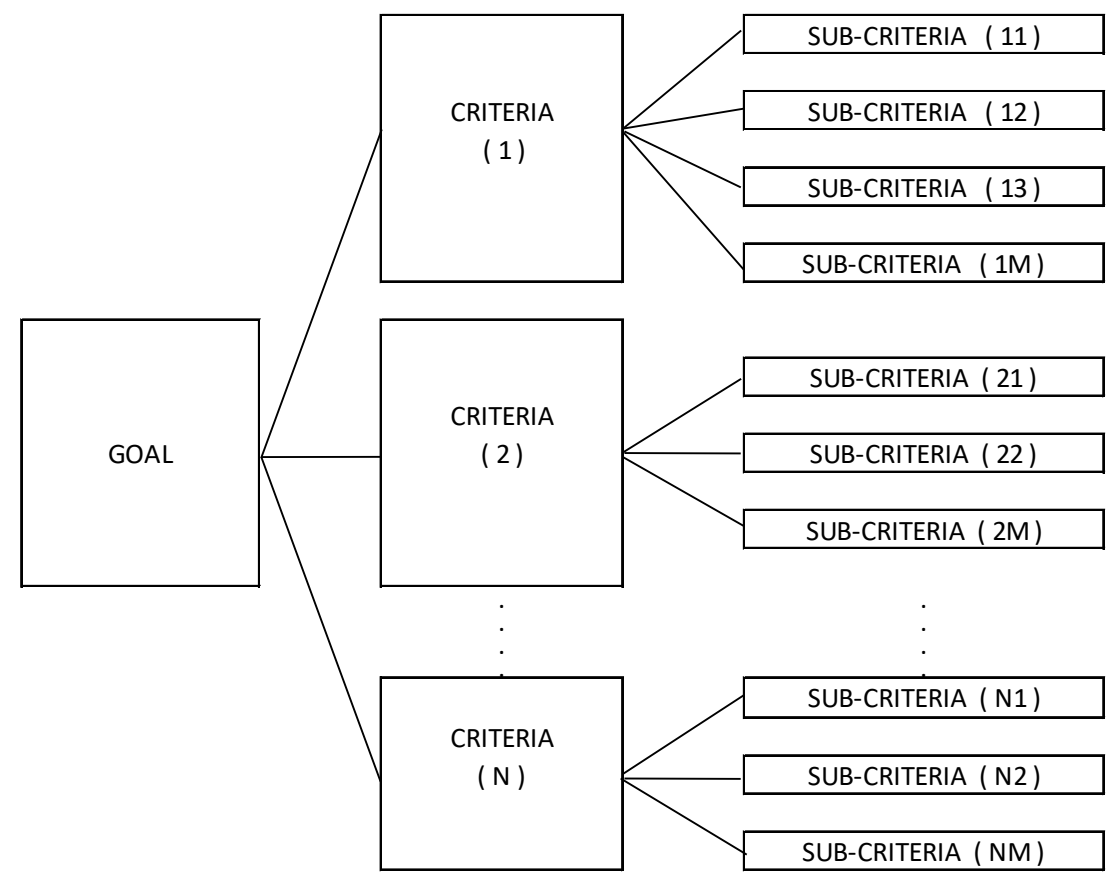

Figure. 1 Example of a general hierarchical framework. Source: Riahi (2010).

To produce a more easily manageable framework it was necessary to group these tems together. Previous research (D'Este and Meyrick, 1992) has demonstrated that the grouping of factors which influence modal choice into broad categories is feasible. Each term was gathered together with other similar terms and then these collections were issued with a heading that reflected the nature of the group. Each of the individual headings (criteria) under which the similar factors (sub-criteria) were grouped was also given a relevant title.

\section{Construct a modal choice decision making framework (Step Three)}

The hierarchic al structure constructed to represent the modal choice decision making process is divided into three levels. These are: Goal, Criteria, and Sub-Criteria (Fig.1). The Goal in this paper is to study the modal choice decision making process between road, rail and water in the Atlantic Gateway of North West England. The criteria are the titles that were allocated in step two to describe the similar sub-criteria grouped beneath them. The sub-criteria are the factors that were identified, through discussions with industry and review of relevant literature, as having a role to play in the decision making process.

Utilising the established criteria headings a concise framework was generated with the purpose of modelling the modal choice decision making process occuming in the Atlantic Gateway of North West England. 


\section{RESULTS}

The purpose of this paper is not to produce a data set but instead to generate a framework for modelling the modal choice decision making process in North West England's Atlantic Gateway. With this being the case there are no practical results to be displayed. The framework itself (Fig.2) constitutes the results.

In this paper the main criteria of the framework serve as umbrella categories whose purpose it is to allow various sub-criteria to be united under a single heading. The criteria selected to meet this objective are:

A. Service - Under which the sub-criteria that affect the perceived quality of the available transport a re grouped.

B. Route - Under which the sub-criteria that identify the characteristics of a chosen route are grouped.

C. Camier - Under which the sub-criteria that detemine the procedural effectiveness of the company providing the transport service are grouped.

D. Shipper-Under which the sub-criteria that influence the person making the freight transport decision as they operate within their own organisation.

In this paper the sub-criteria selected to populate each of the main criteria groups of the framework are:

A1. Administration - The timeliness, efficiency, and accuracy of the administrative processes involved with moving a shipment from its orig in to its destination.

A2. Cost - The total cost of moving a shipment from its origin to its destination.

A3. Delays - The punctual a rival of ship ments at their destination.

A4. Traceability - The real time tracking of cargo after it has been dispatc hed.

A5. Controllability - The ability to control a shipment a fter it has been dispatched.

A6. Value Added Services - The ancillary service options offered to compliment the core service. These are something extra that is typic ally provided at no additional charge.

B1. Transit Time - The time taken to move a shipment from its orig in to its destination.

B2. Frequency - The number of joumeys ca mied out by a transport mode between a shipment's orig in and destination over a given period of time.

B3. Distance - The distance travelled by a shipment from its orig in to its destination.

B4. Capability - The physical facilities and processes available to meet the needs of the shipper.

B5. Extemal Impacts - The pollution and other extemalities resulting from the movement of a shipment from its origin to its destination.

B6. Security - The security of the supply cha in between the shipments origin and destination.

C1. Finances - The size of the ca mier company and its fina ncial sta bility a s perceived by its users.

C2. Damage/Loss - The camier's history of shipment loss and damage.

C3. Claims Processing - The ease by which the camier finalises settlements to cover loss, damage, over charge, or other complaints.

C4. Flexibility - The ability of the camier to accommodate the varying requirements imposed upon them by customers.

C5. Certification - The management systems that are in place within the camer organisation and which are recognised by ISO (or equiva lent) a wards.

C6. Safety Record - The ca mier's history of injuries, fires, fa ta lities, collisions, groundings, a nd a ny other accidents resulting from the transportation of shipments between their origin and destination.

C7. Image of Mode - The public image of the transport mode most commonly associated with the camier.

D1. Market Considerations - What is going on in the shippers chosen market? The market factors that influence the decision maker from outside the shipper's organisation.

D2. Location - The position of the shipper with regards to freight transport infrastructure and the level of access that this offers to each mode. 


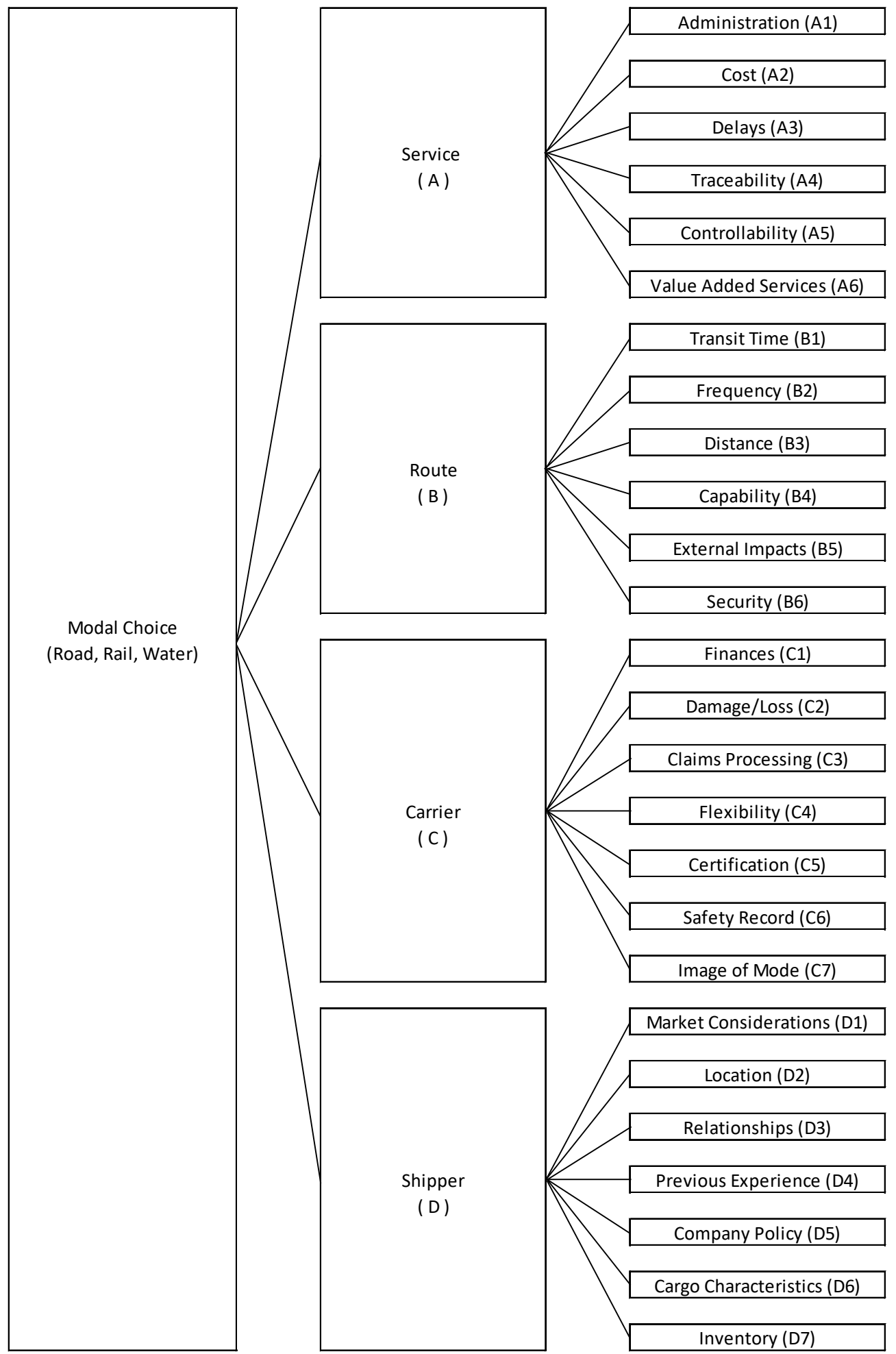

Figure 2. Framework for modelling the modal choice decision making process.

D3. Relationships - The condition of existing relationships that the shipper has with its existing (but a lso potential) suppliers, c a mier companies, and customers.

D4. Previous Experience - The shipper's level of satiffaction with the outcome of previous cargo shipments.

D5. Company Policy - The company polic ies that influence the decision maker intemally within the shipper's organisation. 
D6. Cargo Characteristics - The nature of the cargo being transported. Is it hazardous, perishable, out of gauge, or likely to conta mina te other cargoes?

D7. Inventory - The inventory levels held by the shipper. Is the shippers supply cha in push or pull focused?

\section{CONCLUSION AND RECOMMENDATION}

A significant body of research aimed at identifying the factors that influence modal choice already exists. How these factors combine to reflect the modal choice decision making process that occurs in the mind of the decision maker has been covered to a lesser extent. The review of relevant literature that was undertaken for the purpose of generating the framework produced in this paper demonstrates that it is possible to construct a hierarchical framework of the modal choice decision making process occuring within the geographical area of the Atlantic Gateway. The prospect of producing a generic model of the modal choice decision making process is a much more challenging one. Modal choice is strongly influenced by the infrastructure limitations and geographical constra ints of the location in which the decision is being made.

The next phase of research in to modal choice in the Atlantic Gateway will be to collect data for each of the criteria and sub-criteria that make up the framework in this paper. When expert opinion can be utilized to apply weights to each of them it will be possible to identify those that make up the majority of the weight in the decision making process. The next phase of work on this topic will identify the weight of each of the criteria and sub-criteria by using the Analytic Hierarchy Process (AHP).

With the relevant weights, best and worst solutions identified it would then be prudent for any future modal share policies devised to influence the decision makers of the Atlantic Gateway to use this information as there centre piece. For instance, policies could be developed where a combination of the most heavily weighted factors (identified through AHP) could be utilized in an attempt to make the less popular modes of freight transportation (identified through TOPSIS) more acceptable altematives to North West England's log istic s industry.

Manusc ript received by $24 \mathrm{~J}$ anuary 2017.

\section{REFERENCES}

Abshire, R.D. \& Premeaux, S.R. (1991). Motor ca mier selection criteria: Perceptual differences between ship pers and ca miers. Transportation J oumal. 31(1), 31-35.

Ballou, R.H. \& DeHayes, D.W. (1967). Transportation Selection by Interfim Analysis. Transportation and Distribution Management. 7(6), 33-37.

Bardi, E.J., Bagchi, P.K. \& Raghunathan, T.S. (1989). Motor carrier selection in a deregulated environment. Transportation J oumal. 29(1), 4-11.

Beresford, A.K. (1999). Modelling freight transport costs: A case study of the UK-Greece corridor. Intemational J oumal of Logistic s: Research and Applications. 2(3), 229-246.

Beuthe, M. \& Bouffioux, C. (2008). Analysing qualitative attributes of freight transport from stated orders of preference experiment. Joumal of Transport Ec onomics and Polic y. 42(1), 105-128.

Bird, J. (1988). Freight forwarders speak: the perception of route competition via seaports in the European Communities Research Project - Part 2. Maritime Policy and Management. 15(2), 107-125.

Branch, A.E. (1986). Elements of Port Operation and Management. London: Chapman and Hall.

Brooks, M.R. \& Trifts, V. (2008). Short sea shipping in North Americ a: understanding the requirements of Atlantic Cana dian shippers. Maritime Polic y and Management. 35(2), 145-158. DOI: 10.1080/03088830801956805. 
Cheshire and Wamington Local Enterprise Partnership (2014). Atlantic Gateway: Britain's second engine of growth. Retrieved March 14, 2016, from http:// www.871candwep.co.uk/strategicpriorities/atlantic -gateway/

Crum, M.R. \& Allen, B.J . (1997). A longitudinal assessment of motor camier-shipper relationship trends, 1990 vs. 1996. Transportation J oumal. 37(1), 5-17.

Cullinane, T. \& Toy, T. (2000). Identifying influential attributes in freight route/mode choic e decisions: a content analysis. Transportation Research Part E: Logistics and Transportation Review. 36(1), 41-53. DOI: 10.1016/S1366-5545(99)00016-2.

Danielis, R., Marcucci, E. \& Rotaris, L. (2005). Logistics managers' stated preferences for freight senvice attributes. Transportation Research Part E: Logistics and Transportation Review. 41(3), 201-215. DOI: 10.1016/j.tre.2004.04.003.

Department for Transport (2007). Freight Best Practice: Choosing and Developing a Multi-modal Transport Solution. London: Her Majesty's Stationery Office (HMSO).

D'Este, G.M. (1992). Camier Selection in a RO/RO femy trade. Part 2: Conceptual framework for the decision process. Maritime Polic y and Management. 19(2), 127-138. DOI: 10.1080/03088839 200000020.

D'Este, G.M. \& Meyrick, S. (1992). Ca mier Selection in a RO/RO femy trade. Part 1: Decision factors and attitudes. Maritime Policy and Management. 19(2), 115-126. DOI: 10.1080/03088839200 000019.

de Jong, G.C., Gommers, M.A. \& Klooster, J.P.G. (2000). Time Valuation in Freight Transport: methods and results. In: de Ortuzar, J.D. (Ed.) Stated Preferences Modelling (pp.231-242). London, PTRC Education and Research Services.

de Oses, F. X. M. \& Castells, M. (2008). Selection of Short Sea Shipping transport altematives in SW Europe. Polytechnic University of Catalonia, Barcelona, Spain.

Dial, R.B (1979). A model and algorithm for multi-c riteria route-mode choice. Transportation Research Part B: Methodologic al. 13(4), 311-316. DOI: 10.1016/0191-2615(79)90024-9.

Dobie, K. (2005). The core shipper concept: a proactive strategy for motor freight camiers. Transportation J oumal. 44(2), 37-53.

European Commission (2001). European Transport Policy for 2010: Time to Decide - White Paper COM (2001) 370 final. Luxembourg: Office for Offic ial Public ations of the European Communities.

European Commission (2003). Marco Polo - New Ways to a Green Horizon. Retrieved J uly 16 2014 , from http://ec.europa.eu/transport/marcopolo/

European Commission (2006). Maritime Transport - Motorways of the Sea. Retrieved J anuary $22^{\text {nd }} 2014$, from http://ec .europa.eu/transport/modes/maritime/motorways_sea_en

Evers, P.T. \& Johnson, C.J. (2000). Performance Perceptions, Satisfaction, and Intention: The Intermodal Shipper's Perspective. Transportation J oumal. 40(2), 27.

Feo, M., Espino, R. \& Garcia, L. (2011). A stated preference analysis of Spanish freight forwarders modal choice on the south-west Europe Motorway of the Sea. Transport Policy. 18(1), 60-67. DOI: 10.1016/j.tranpol.2010.05.009.

Feo-Valero, M., Garcia-Menendez, L., Saez-Ca rramolino, L \& Furio-Prunonosa, S. (2011). The importance of the inland leg of containerised maritime shipments: An analysis of modal choice determinants in Spain. Transportation Research Part E: Logistics and Transportation Review. 47(4), 446-460. DOI: 10.1016/j.tre.2010.11.011.

Fremont, A. \& Franc, P. (2010). Hinterland transportation in Europe: Combined transport versus road transport. Joumal of Transport Geography. 18(4), 548-556. DOI: 10.1016/j.jtrangeo.2010.03.0 09.

Garcia-Menendez, L. \& Feo-Valero, M. (2009). European Common Transport Policy and Short-Sea Shipping: Empincal Evidence Based on Modal Choice Models. Transport Reviews. 29(2), 239-259. DOI: 10.1080/01441640802357192.

Gouvemal, E., Slack, B. \& Franc, P. (2010). Short sea and deep sea shipping markets in France. Joumal of Transport Geography. 18(1), 97-103. DOI: 10.1016/j.jtrangeo.2009.05.004. 


\section{Log istics \& Susta ina ble Tra nsp ort \\ Vol. 8, No. 1, May 2017, 19-30 \\ doi: $10.1515 /$ jlst-2017-0002}

Gray, R. (1982). Behavioural approaches to freight transport modal choice. Transportation Review. 2(1), 161184. DOI: 10.1080/01441648208716491.

Grosso, M. (2011). Mode Choic e: Road transport versus intermodal transport: An analysis applied to the Port of Genoa and the port of Antwerp. University of Antwerp, Antwerp, Belgium; University of Genoa, Genoa, Italy.

Gursoy, M. (2010). A method for transportation mode choic e. Scientific Research and Essays. 5(7), 613-624.

Hjelle, H.M. (2010). Short Sea Shipping's Green Label at Risk. Transport Reviews. 30(5), 617-640. DOI: 10.1080/01441640903289849.

Kent, J.L. \& Parker, R.S. (1999). Intemational containership ca mier selection criteria. Intemational J oumal of Physic al Distribution and Logistic s Management. 29(6), 398-408. DOI: 10.1108/0960 0039910283613.

Konings, R. \& Ludema, M. (2000). The competitiveness of the river-sea transport system: market perspectives on the United Kingdom-Germany comidor. Joumal of Transport Geography. 8(3), 221-228. DOI: 10.1016/S0966-6923(00)00015-6.

Mangan, J ., La Iwani, C. \& Gardner, B. (2001). Identifying Relevant Variables and Modelling the Choice Process in Freight Transportation. Intemational Joumal of Maritime Economics. 3(3), 278-297. DOI: 10.1057/palgrave.ijme.9100017.

Mangan, J., Lalwani, C. \& Gardner, B. (2002). Modelling port/femy choice in RoRo freight transportation. IntemationalJ oumal of Tra nsp ort Management. 1(1), 15-28. DOI: 10.1016/S1471-4051(01)00003-9.

Matear, S. \& Gray, R. (1993). Factors Influencing Freight Service Choice for Shippers and Freight Suppliers. Intemational Joumal of Physical Distribution \& Logistics Management. 23(2), 25-35. DOI: 10.1108/09600039310038198.

McGinnis, M.A. (1979). Shipper Attitudes Towards Freight Transportation Choice: A Factor Analytical Study. Intemational Joumal of Physical Distribution \& Logistics Management. 10(1), 25-34. DOI: $10.1108 /$ eb014464.

McGinnis, M.A. (1989). A comparative evaluation of freight transportation choice models. Transportation J oumal. 29(2), 36-46.

Meixell, M.J . \& Norbis, M. (2008). A review of the transportation mode choice and camier selection literature. Intemational J oumal of Logistic s Mana gement. 19(2), 183-211. DOI: 10.1108/09574 090810895951.

Menon, M.K., McGinnis, M.A. \& Ackerman, K.B. (1998). Selection Criteria for Providers of Third-Party Logistic S Servic es: An exploratory Study. J oumal of Business Logistics. 19(1), 121-137.

Murphy, D.J . \& Famis, M.T. (1993). Time-based strategy and camier selection. J oumal of Business Logistics. 14(2), 25-40.

Murphy, P., Daley, J. \& Hall, P. (1997). Camier selection: do shippers and camiers agree, or not? Transportation Research Part E: Logistics and Transportation Review. 33(1), 67-72. DOI: 10.1016/S1366-5545(96)00003-8.

Paixao, A. \& Marlow, P. (2001). A review of the European Union shipping policy. Maritime Policy and Mana gement. 8(2), 187-198. DOI: 10.1080/03088830118389.

Paixao, A. \& Marlow, P. (2002). Strengths and weaknesses of short sea shipping. Marine Polic y. 26(1), 167-178. DOI: 10.1016/S0308-597X(01)00047-1.

Premeaux, S.R. (2002). Motor camier selection criteria: perceptual differences between shippers and motor ca miers. Tra nsportation J oumal. 42(2), 28-38.

Premeaux, S.R. (2007). Motor Ca miers' and Shippers' Perceptions of the Camier Choice Decision. Joumal of the Transportation Research Forum. 46(3), 5-12.

Punakivi, M. \& Hinkka, V. (2006). Selection criteria of transportation mode: a case study in four Finnish industry sectors. Transport Reviews. 26(2), 207-219. DOI: 10.1080/01441640500191638.

Riahi, R. (2010). Enabling security and risk-based operation of container line supply chains under high uncertainties. Unpublished doctoral dissertation, Liverpool J ohn Moores University, Liverpool, United Kingdom. 


\section{Log istics \& Susta ina ble Tra nsp ort \\ Vol. 8, No. 1, May 2017, 19-30 \\ doi: 10.1515/jlst-2017-0002}

Rich, J., Holmblad, P.M. \& Hansen, C.O. (2009). A weighted logit freight mode-choice model. Transportation Research Part E: Logistics and Transportation Review. 45(6), 1006-1019. DOI: 10.1016/j.tre.2009.02.001.

Shinghal, N. \& Fowkes, T. (2002). Freight mode choice and adaptive stated preferences. Transportation Research Part E: Logistic s and Transportation Review. 38(5), 367-378. DOI: 10.1016/S1366-5545(02)00012-1.

The Peel Group (2012). Atlantic Gateway. Retrieved 24th August 2016, from http://www.atlantic ga teway.co.uk/

Torbianelli, V.A. (2000). When the road controls the sea: a case study of Ro-ro transport in the Mediterranean. Maritime Policy and Management. 27(4), 375-389. DOI: 10.1080/0308883004 16568.

Vellay, C., \& de Jong, G. (2003). A Simultaneous SP/RP Analysis of Modal Choice in Freight Transport in the Region Nord - Pas-de-Cala is. Retrieved August 25th 2014, from http://www.rand .org/p ubs/monograph_reports/2005/MR1435.pdf

Voss, M.D., Page, T.J., Keller, S.B. \& Ozment, J. (2006). Determining important camier attributes: a fresh perspective using the theory of rea soned action. Transportation J oumal. 45(3), 7.

Wong, P.C., Yan, H. \& Bamford, C. (2008). Evaluation of factors for camier selection in the China Pearl River delta. Maritime Policy and Mana gement. 35(1), 27-52. DOI: 10.1080/030888307018 48854. 